A N N A LES

UNIVERSITATIS MARIAE CURIE-SKŁODOWSKA

LUBLIN - POLONIA

VOL. LXVI, 1, 2

SECTIO AA

2011

\title{
The studies of the natural zeolite - clinoptylolite in reduction of nitrogen*
}

\author{
W. Ćwikła-Bundyra \\ Institution of Environmental Chemistry, UMCS \\ Pl. Marii Skłodowskiej - Curie 3, 20-031 Lublin, Poland \\ E-mail:wieslawa.cwikla-bundyra@ poczta.umcs.lublin.pl, tel. (081) 5375692
}

This article presents the results of the research in the area of the possibilities of the utilization of natural zeolite- clinoptylolite for reduction of oxide nitrogen. The clinoptylolite type zeolite has the unique structure, high resistance against hydrothermal conditions and the ability to form strong acid centers. Various kinds of metals ions were inserted into the samples of zeolite using ion-exchange method. The effect of metals content was shown for clinoptylolite matrix and related to the performance of its pure hydrogen form. A comparison of the catalytic properties of $\mathrm{Cu}-, \mathrm{Co}$-, Fe-, Mn- and Ni-CLI was carried out for the NO reduction with methane. A eries of doubly substituted CoCu-CLI catalysts with different metal loading were studied too. Over the copper and cobalt-CLI was observed high nitric oxide conversion, especially at temperatures between 400 and $500^{\circ} \mathrm{C}$. It was confirmed that the copper-cobalt-CLI catalysts have higher activity and durability than catalysts composed of iron, nickel and manganese supported on clinoptylolite. Moreover, the iron, nickel and manganese containing catalysts produced more nitrous oxide than nitrogen. The presence of both copper and cobalt species seems to be an indispensable condition for the high activity and selectivity in the NO reduction.

* This article is dedicated to Professor Dobiesław Nazimek on the occasion of his $65^{\text {th }}$ birthday 


\section{INTRODUCTION}

Zeolite are this natural or synthetic aluminosilicates built from $\mathrm{AlO}_{4}$ and $\mathrm{SiO}_{4}$, created well ordered crystallographic net, in which oxygen create corner tetrahedral. The different degree of oxidation of silicon and the character is useful the aluminum to them the electronegative. The proportion of number of $\mathrm{Al}$ :Si the size of negative load be determined, which for majority natural zeolite has contained in borders since 1:1 to 1:6 [1-3]. Movable cation load this be compensated, which can freely move in grounds of structure of mineral. The size of negative load decides about capacity sorption, ionic renewable and catalytic. Tetrahedral building aluminosilicate is useful them the character of molecular sieve folded from many tunnels, polyhedral spaces, arranged simultaneously in one direction, in two on plane or atomic in three directions, which depends from kind zeolite. It was distinguished at present about 60 different natural skeletons zeolite $[2,3]$. The most widespread and creator the largest supplies zeolite the zeolite is the siliceous - the clinoptylolite the belonging to group from row heulandyt, characterize the value of relation $\mathrm{Si}$ : Al larger from 4 as well as the content of cation $(\mathrm{Na}+\mathrm{K})>(\mathrm{Ca}+\mathrm{Ba}+\mathrm{Sr})$ [2-4]. Zeolite this marks many specific features physical chemistry, such how: high capacity sorption and ionic renewable, selectivity ability molecular-sieve, catalytic activity as well as structural thermo stability in temperatures to $700 \div 750^{\circ} \mathrm{C}$, which then proprieties be used in many fields of present technique. Particularly essential part aluminosilicate play in protection of environment. Magnificent oneself to be they effective in absorption of poisonous components of combustion gases, clinoptylolite and mordenite was applied to removing $\mathrm{SO}_{2}$ from streams of gases and smokes from factory chimneys across zeolite adsorbers-catalysts [5-7]. The dirt of natural environment has with development of motorization the exact relationship. The reinforced with hydro carbonaceous fuels cars contribute to enlargement of to atmosphere of toxic relationships the emission significantly. The solid particles in engines of cars the most harmful components of fumes are and the oxides of nitrogen [8-10]. To the limit their emission new constructional solutions were sought. They be base mainly on use the pose of motor methods of limiting the emission of toxic substances. The most promising the catalysts, if $\mathrm{NO}_{\mathrm{X}}$ walks about limitation of emission, seem to be the selectively reducing oxides of nitrogen (the SCR - the $\mathrm{NO}_{\mathrm{X}}$ ). They as reducers of oxides of nitrogen use ammonia or hydrocarbons. Catalysts these assure over $80 \%$ conversion. We to modify these arrangements can to replenish about suitable active component the composition of catalyst. They fulfill the part of active components the most often copper, cobalt as well as noble metals [11,12]. In catalysts zeolite the most often complies ZSM-5, mordenite and ferrierite. Copper fulfils the part of active component the most often [13-16]. Catalysts these characterize low temperature, 
the process of conversion in which begins NO. The maximum degree of conversion be achieved in temperature $385^{\circ} \mathrm{C}[16,17]$. Use in world grows up continually zeolite to partial reduction $\mathrm{CO}, \mathrm{NO}_{\mathrm{x}}$ and hydrocarbons in products burning. In relationship from this, it that was one should was clinoptylolite him group zeolite high siliceous how remembered higher mordenite or ferrierite, question pushes zeolite this can characterize with good catalytic proprieties replenished with suitable active metal.

In the results of investigations of utilization over possibility in article were introduced the natural zeolite - the clinoptylolite to reduction of toxic pollutions of combustion gases. It the advantage of use was estimated very cheap and easy to gain over to reduction catalytic material NO in laboratory scale.

\section{STUDIED CATALYSTS}

It was executed was six catalysts leaning on clinoptylolite (about size of grain about $1.2 \mathrm{~mm}$ ) modified for help of suitable active metal. Zeolite in figure sodium- potassium was conducted was in hydrogen figure, for what he was subjected ion exchange for help of suitable salts of metals: $\mathrm{Cu}, \mathrm{Co}, \mathrm{Ni}, \mathrm{Mn}, \mathrm{Fe}$ as well as $\mathrm{Cu}$ and $\mathrm{Cd}$ simultaneously. In the distilled water was washed was the received precursory, one dried and the calcinations in atmosphere of air. Analysis was subjected received catalysts physical chemistry. It introduced to zeolite the content of individual metals the spectrophotometer was marked for help the AAS, Spektr AA 800, after previous mineralization of sample for help microwave mineralizes, Mars 5, in Central Analytic Laboratory in Lublinie. It the method was qualified the general surface of studied samples the BET by measurement of adsorption of argon in temperature of liquid nitrogen in statically determinate - the volumetric apparatus, assuring vacuum $5 \times 10^{-9} \mathrm{mmBa}$ in Studio the Porosimeter for help of apparatus ASAP 2405, Micrometrics the Inc. USA as well as Autosorb-1CMC, Quantachrome Instruments, USA. The analysis of isotherms of adsorption was conducted for received samples the BET applying the nitrogen. It the isotherm of adsorption, proper surface was marked as well as volume and surface proper micro pore. It the method was marked was to matrix the content of introduced cation of metal the zeolite the XRF as well as the AAS In Central Analytic Laboratory of Maria's University the CurieSkłodowska in Lublin. 
Tab. 1. Characteristic of the clinoptylolite catalysts.

\begin{tabular}{|c|c|c|c|c|c|}
\hline Catalysts & $\begin{array}{c}\% \text { of weight of } \\
\text { metal }\end{array}$ & $\begin{array}{c}\text { Relation } \\
\text { of weight } \\
\mathrm{Me} / \mathrm{Al}\end{array}$ & $\begin{array}{c}\text { Surface } \\
\text { area } \\
{\left[\mathrm{m}^{2} / \mathrm{g}\right]}\end{array}$ & $\begin{array}{c}\text { Volume } \\
\text { micropore } \\
{[\mathrm{cc} / \mathrm{g}]}\end{array}$ & $\begin{array}{c}\text { Surface } \\
\text { micropore } \\
{\left[\mathrm{m}^{2} / \mathrm{g}\right]}\end{array}$ \\
\hline Fe-CLI & $4.00 \%$ & 0.356 & 24.2436 & 0.003912 & 8.9073 \\
\hline $\mathrm{Co}-\mathrm{CLI}$ & $4.05 \%$ & 0.369 & 27.1913 & 0.000998 & 2.3026 \\
\hline $\mathrm{Ni}-\mathrm{CLI}$ & $2.50 \%$ & 0.228 & 21.4426 & 0.002381 & 5.4259 \\
\hline $\mathrm{Cu}-\mathrm{CLI}$ & $4.00 \%$ & 0.369 & 26.7563 & 0.003155 & 7.1974 \\
\hline $\mathrm{Mn}-\mathrm{CLI}$ & $2.90 \%$ & 0.265 & 11.9791 & 0.001025 & 2.3312 \\
\hline $\mathrm{CoCu}-\mathrm{CLI}$ & $4 \% \mathrm{Co} / 2.9 \% \mathrm{Cu}$ & 0.630 & 32.9996 & 0.003108 & 4.8389 \\
\hline
\end{tabular}

The weight percentage of introduced metal hesitates on two levels. It was introduced $4 \%$ weights. What, $\mathrm{Cu}$ and $\mathrm{Fe}$, however $\mathrm{Ni}$ and $\mathrm{Mn}$ make up ok. 3\% weights introduced metal in structure clinoptylolite. To result this may be from their ability ionic renewable. Clinoptylolite undergoes the effective exchange of bivalent cation from following row peaceably: $\mathrm{Cu}, \mathrm{Zn}$, What, $\mathrm{Fe}, \mathrm{Mn}, \mathrm{Ni}$. Relation oscillates to $\mathrm{Al}$ weight metal in small range and it is the result of incomplete compensation of excess negative load, stepping out in clay zeolite. The surface the BET does not show the considerable divergences, which be caused the substitution in net the new cation in road of exchange.

\section{INVESTIGATION OF ACTIVITY OF CATALYSTS IN DEPENDENCE FROM TEMPERATURE OF CATALYTIC PROCESS}

Investigation was conducted on laboratory investigative position folded from: the dosing the substrata part that is so the $\mathrm{CH}_{4}$, reactor the no gradient together with arrangement of control of temperature as well as the gas chromatograph to analyzing the products of reaction.

Through reactor the no gradient swam the oxide of nitrogen $(1500 \mathrm{ppm}$ $\mathrm{NO} / \mathrm{He})$, the methane $\left(4000 \mathrm{ppm} \mathrm{CH}_{4} / \mathrm{He}\right)$ as well as the fulfilling the function of gas hydrogen cooling the reactor. It the stream of gases was controlled was near help of regulators of flow, for what he was brought to mixer. The studied catalyst before accomplishment of measurements was reduced in atmosphere of hydrogen. The temperature of work of reactor be steered near use the regulator - 
Trol 8120, joint from being in deposit of catalyst thermocouple. The goes out from reactor gases be analyzed near help of gas chromatograph (the SRI Model $8610 \mathrm{C}$ ) integrated from computer of PC. Resistance connected from small diameter the capillary tube of chromatograph be compensated near of pump connected to arrangement help. It the intensity of flow of gases near help of needle valve was controlled was, so to it was lower than flow feeding reactor gases.

The TOF the speed of process was expressed for help (the turnover the frequency) that is maximum number of particles of substratum what catalyst can convert to product in individual of time. It she was counted was with measurement of degree reacting with example peaceably [10]:

$$
r=\left[F\left(C_{\text {in }}-C_{\text {out }}\right) /\left(W \cdot 2 V_{H 2} / V_{M}\right)\right]
$$

where: the $\mathrm{r}$ - the speed of reaction $\left(\mathrm{s}^{-1}\right), \mathrm{W}-$ the mass of sample of catalyst (the $\mathrm{g}$ ), the $\mathrm{F}$ - the volume of flow the NO through reactor (the mole/the s), the $\mathrm{C}_{\mathrm{in}}$, $\mathrm{C}_{\text {out }}$ - the entrance and the exit concentration $\mathrm{NO}, \mathrm{V}_{\mathrm{H} 2}$ - the volume of hydrogen the chemisorbs by sample $\left(\mathrm{cm}^{3} /\right.$ the $\left.\mathrm{g}\right), \mathrm{V}_{\mathrm{M}}$ - the molar volume of hydrogen.

It the dependence of speed and the method was marked the selectivity of reaction the izo - the $\mathrm{x}$, depending on delimitation near solid degree of conversion, on basis of change of flow reacting substances the speed of reaction the and measured mass the used catalyst $[18,19]$.

It the degree of conversion of substrate was counted was near utilization example:

$$
\mathrm{X}_{\mathrm{NO}}=\left[C_{N O}^{0}-C_{N O} / C_{N O}^{0}\right]
$$

where: $\mathrm{C}_{\mathrm{NO}}^{0}-$ concentration $\mathrm{NO}$ on entry to reactor $-\left(\mathrm{mole} / \mathrm{dm}^{3}\right), \mathrm{C}_{\mathrm{NO}}-$ concentration $\mathrm{NO}$ on exit from reactor $\left[\mathrm{mole} / \mathrm{dm}^{3}\right]$

The degree of conversion the NO to $\mathrm{N}_{2}$ according to dependence $[18,19]$ :

$$
\mathrm{X}_{\mathrm{NO} \text { do } \mathrm{N} 2}=2 C_{N 2} / C_{N O}^{0}
$$

where: $\mathrm{C}_{\mathrm{NO}}-$ concentration $\mathrm{N}_{2}$ on exit from reactor $\left(\mathrm{mole} / \mathrm{dm}^{3}\right), \mathrm{C}_{\mathrm{NO}}-$ concentration on entry to reactor $\left(\mathrm{mole} / \mathrm{dm}^{3}\right.$ )

The speed of reaction is the basis to calculation in studied compartment of temperatures the energy of activation. The energies of activation were appointed on basis of transformed equation the empirical Arrheniusa describing the 
dependence among solid the speed of reaction and the energy of activation and the temperature [20-22]:

$$
E_{a}=-R T \ln (k / A)
$$

where: the $E_{a}$ - the energy of activation (the $\mathrm{kJ} /$ the mole), the $\mathrm{R}$ - stood gas, the $\mathrm{T}$ - the temperature (the $\mathrm{K}$ ), the $\mathrm{k}$ - the solid speed of reaction, $\mathrm{A}$ - the factor the pre-exponential.

In the tested catalysts were introduced was in context of influence two the different parameters example of temperature of process and the kind of cation of metal. It the results of measurements were captured was in correlation of degree the pre-reaction so the temperature of process. It tests were conducted was in relatively low temperatures, so to possible execution on all catalysts reliable tests was. The isothermal measurements for comparison of activity of catalysts in studied reaction were executed. With regard on got small activity of catalysts, minimum temperature for all studied arrangements Me-CLI carried out $300^{\circ} \mathrm{C}$.

When the catalyst is little active, we can steer across change of temperature of reaction with conditions of reaction, the flow of reacting substances or the enlargement the weight. The speed of reaction is limited with porous structure of contact. The measurements were conducted for possibly low compartment of temperatures. It was tried was to picture cut the levels of activity studied catalytic phase in compartment $300-500^{\circ} \mathrm{C}$. From received graphs one read the value of speed of reaction for individual products in the compartment temperatures $300-500^{\circ} \mathrm{C}$, for degree of conversion the $\mathrm{X}_{\mathrm{NO}}=70 \%$. The use of technique of extrapolation speed reaction in function of degree the pre-reacting made possible the obtainment in grounds of studied series of catalysts the results of comparability. It the results of investigations of dependence degree were introduced was pre-reacting NO from temperature of process on Figure 1 and 2.

The highest conversion of oxide of nitrogen have was got in range of temperatures since 450 to $500^{\circ} \mathrm{C}$ for all contacts. Zeolite catalysts of copper and of cobalt permit conversion about $80 \%$. Ferric catalysts, nickel and manganese NO they achieve in range 50 the somewhat lower degree of conversion- $60 \%$. The conversion of oxide of nitrogen looks to nitrogen somewhat differently Figure 3.

Studied catalysts show moderated catalytic being with result abilities got conversion to clean nitrogen. Catalysts $\mathrm{CoCuH}$ - to get CLI permit the highest value $60 \%$ clean nitrogen. It in aim self - characterize the activity of individual catalysts was introduced was on course of process the influence of temperature reductive $\mathrm{NO}$ - Figure 5. 


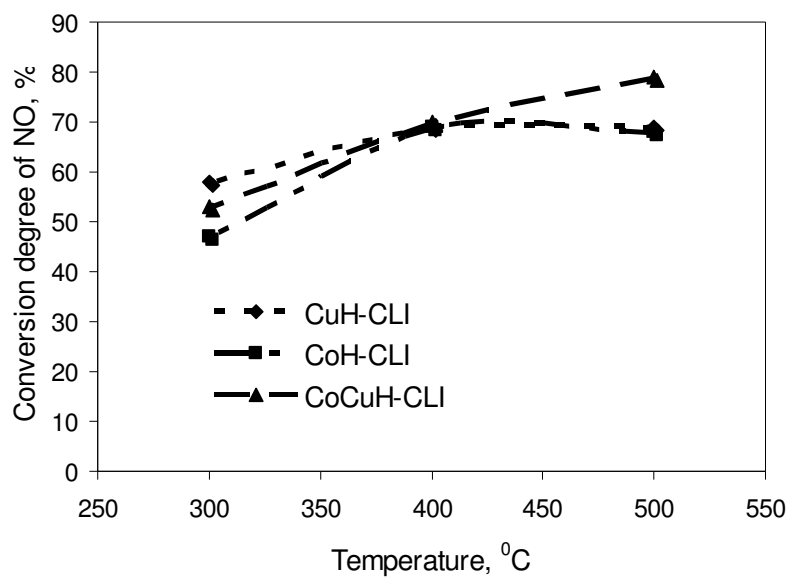

Fig 1. NO conversion over $\mathrm{Cu}, \mathrm{Co}$ and $\mathrm{CoCu}-\mathrm{CLI}$ as function of temperature.

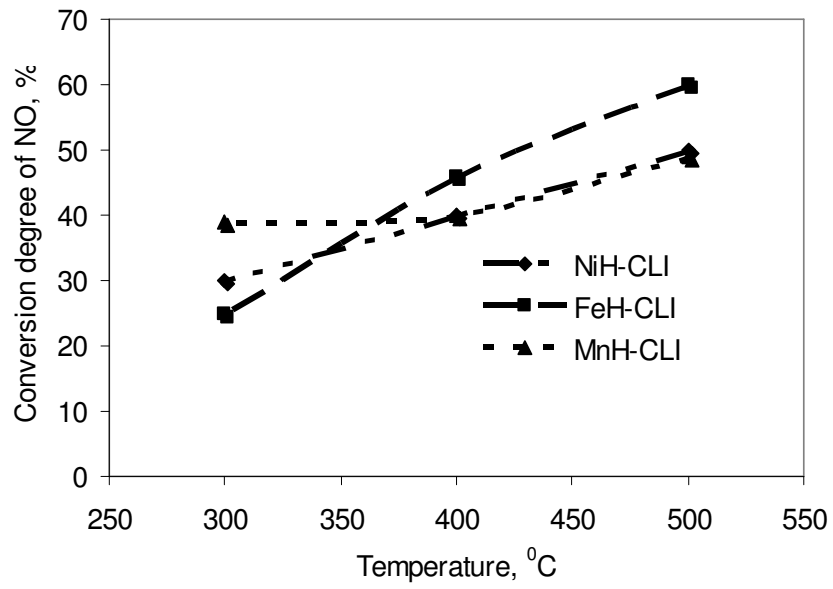

Fig 2. NO conversion over Ni, Fe and Mn-CLI as function of temperature.

It for comparison of catalytic abilities of different cation metals introduced in net clinoptylolite was executed was the composition of degree of conversion $\mathrm{NO}$ for all catalysts in the most profitable temperature of process $\left(500^{\circ} \mathrm{C}\right)$ - Figure 6 .

The most profitable contact with studied series of contacts the modified with different cation of transitory metals clinoptylolite stays the contact the bimetallic CoCuH-CLI, which assures the conversion the NO $80 \%$ above as well as the copper contacts and cobalt on level $65-70 \%$. Remaining catalysts do not check in reduction NO, the got degree of transformation is sale low. It the speed of reaction for studied compartment of temperatures was counted was on individual 
contacts and TOF of that is speed of reaction was introduced in figure brought back to number of active centers in individual of time as well as graphs of Arrhenius [16,17] - Figures 7 and 8.

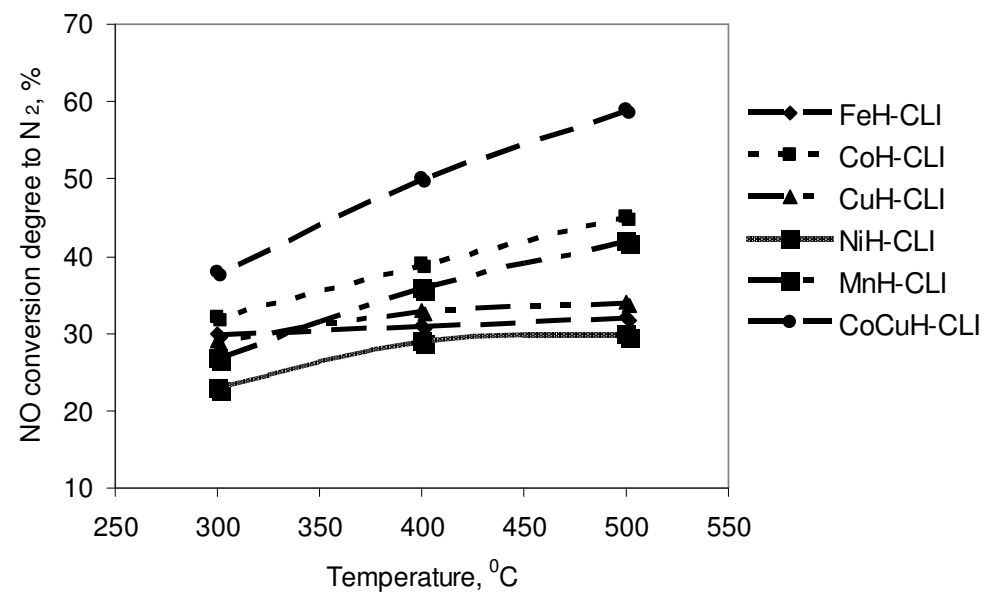

Fig. 3. Dependence of conversion of NO this $\mathrm{N}_{2}$ on temperature in SCR of NO with $\mathrm{CH}_{4}$ over Me(metal)-clinoptylolite.

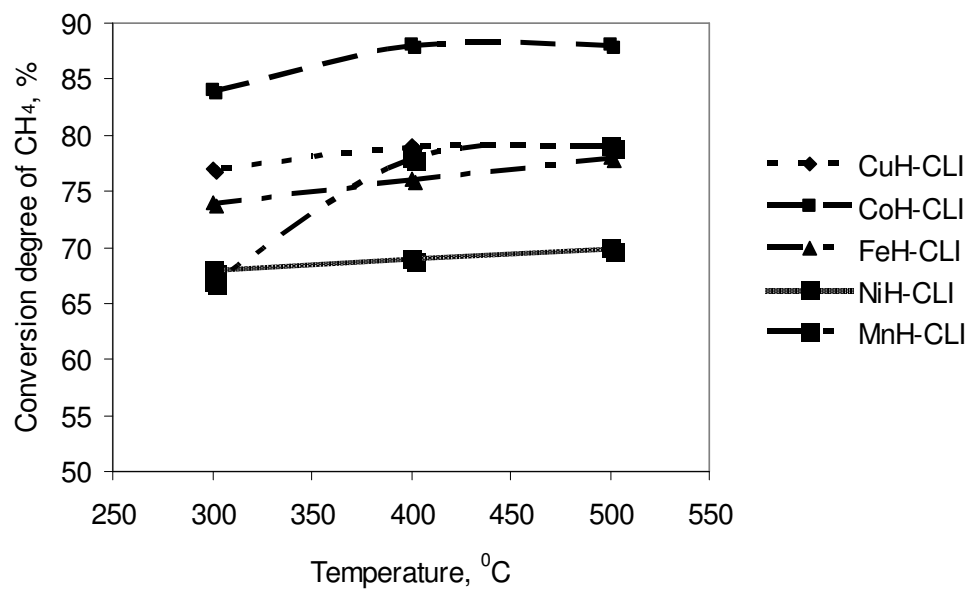

Fig. 4. Dependence of conversion of $\mathrm{CH}_{4}$ on temperature in SCR.

The linear dependences of logarithm of speed reaction from temperature permit to notice, that three of them cut in one the point the temperature the isokinetic. In point this the speeds of reaction for different catalysts are me even. Existence such temperature permit on affirming of presence of compensatory effect and Exner carries the name of criterion [17]. 

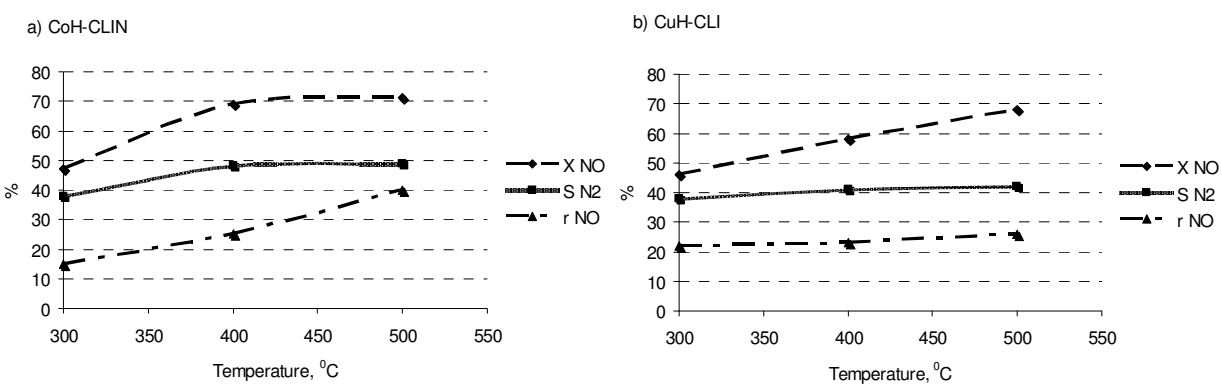

c) CoCuH-CLIN

d) FeH-CLIN
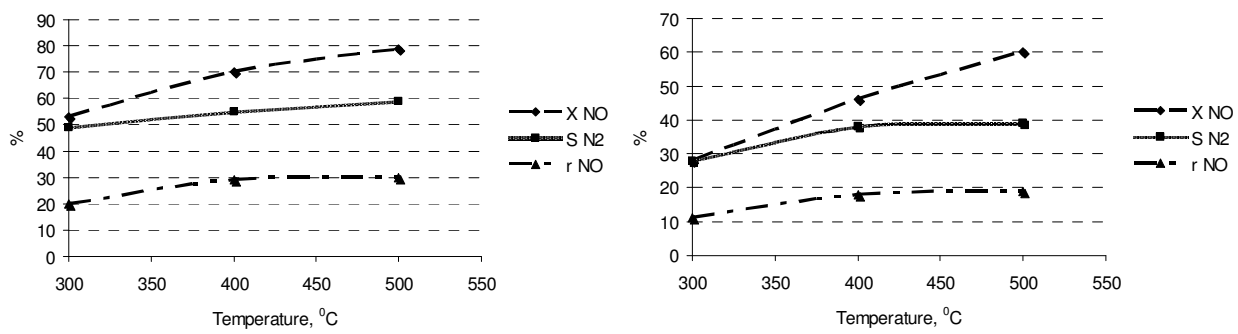

Fig 5. Reduction of nitrogen oxide over clinoptylolite catalysts; $\mathrm{X}_{\mathrm{NO}}$-nitrogen oxide conversion, $\mathrm{r}_{\mathrm{NO}}$ - reaction rate of $\mathrm{mol} / \mathrm{gh}, \mathrm{S}_{\mathrm{N} 2^{-}}$conversion of $\mathrm{NO}$ to $\mathrm{N}_{2}$.

$\mathrm{T}=500{ }^{\circ} \mathrm{C}$

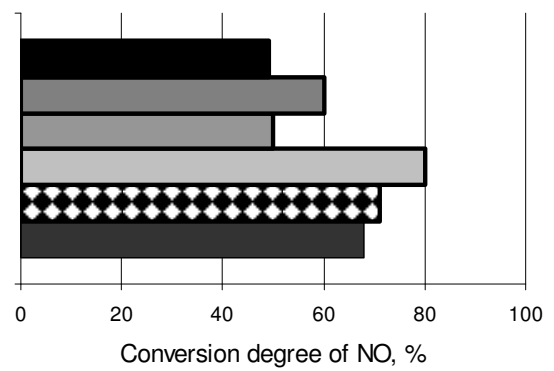

$\mathrm{MnH}-\mathrm{CL}$

口 $\mathrm{FeH}-\mathrm{CLI}$

$\square \mathrm{NiH}-\mathrm{CLI}$

a $\mathrm{CoCuH}-\mathrm{CLI}$

- $\mathrm{CoH}-\mathrm{CLI}$

$\square \mathrm{CuH}-\mathrm{CLI}$

Fig. 6. Dependence of maximum conversion of NO this $\mathrm{N}_{2}$ on the temperature in SCR of $\mathrm{NO}$ with $\mathrm{CH}_{4}$ over Me-clinoptylolite.

Explanation this phenomenon is not unambiguous, the energetic unbalance of surface is the cause probably that is the existence the $n$ of groups the active centers, the run on which can the superficial reaction. The appointed value of temperature the isokinetic makes possible the reading for responsible particle the wave characteristic number for trembling, that is limiting the speed of process doubtless. The delimitation the energy of activation was the next stage of investigations $\left(\mathrm{E}_{\mathrm{a}}\right)-$ Figures 8 and 9 . 
Exner criterion-effect compensation

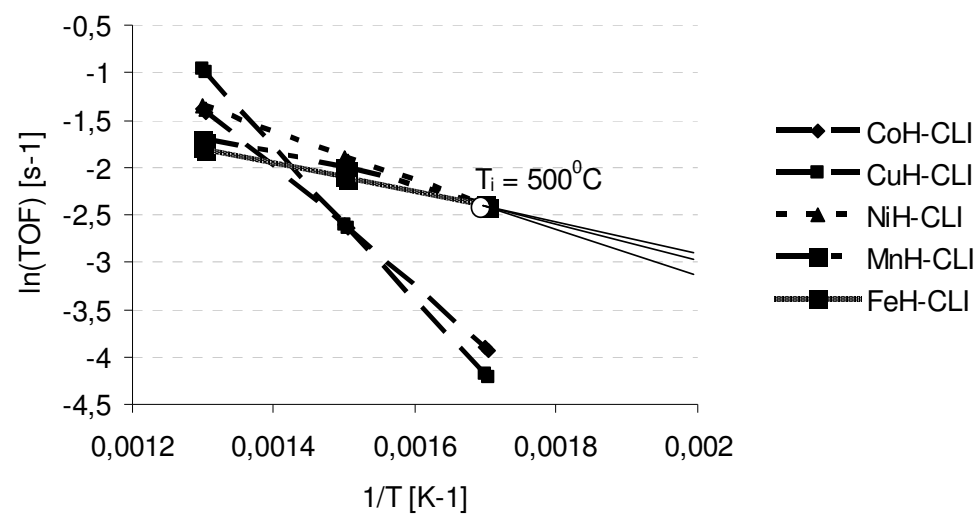

Fig. 7. Correlation between the TOF of NO reduction and the reversed temperature he various kinds of Me-CLI.

For catalysts Mn-CLI and Ni-CLI the got the energy of activation are the lowest line a dozen or so $\mathrm{kJ} / \mathrm{mole}$. Ferric catalyst achieves indirect value $20 \mathrm{~kJ} / \mathrm{mol}$, however copper and cobalt catalysts get the highest energy of activation.

In group of studied catalysts leaning on clinoptylolite the counted values of energy of activation they had contained in compartment since $12.46-67.1 \mathrm{~kJ} / \mathrm{mol}$. The numerical data of got energies of activation were introduced in Table 2 .

When the process of reduction on data catalyst runs with large energy of activation, adsorb particles possess the definite supply of kinetic energy to conquest of energy barrier. Process this depends from temperature and it grows up from her rise together with. It can observe, the energy of activation depends from sizes of geometrical particles not only, but also from chemical nature of particles, that is from intensity their the influence with centers the adsorptive.

\section{DISCUSSION OF RESULTS AND THE CONCLUSIONS}

Conducted investigations over utilization clinoptylolite the modified as catalyst of reduction with different ions of transitory metals NO showed with methane, it that in spite different objects was can find sure dependences. The method of ion exchange to matrix the zeolite was introduced was in solid body the ions of copper, of cobalt, of iron, manganese and the nickel and also the combinations two cation of copper and the cobalt simultaneously. 
a) $\mathrm{CoH}-\mathrm{CLI}$

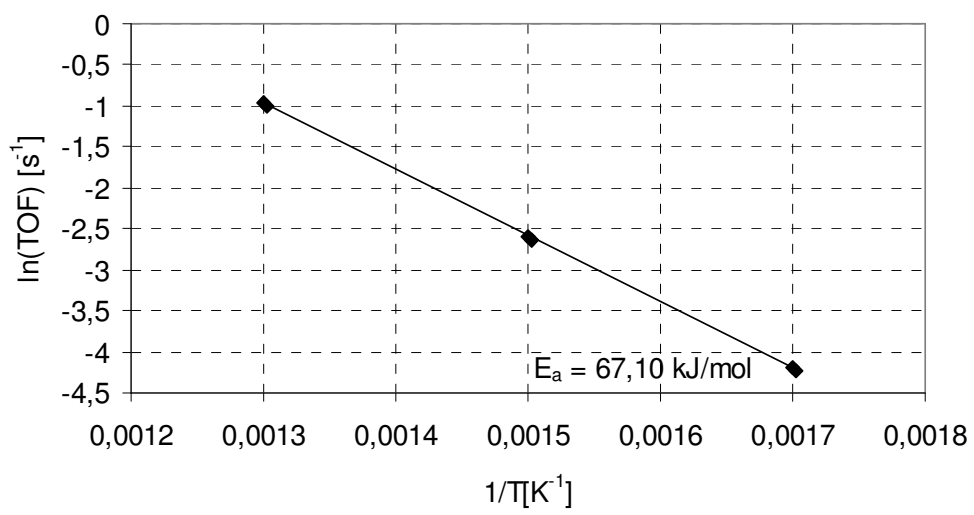

b) $\mathrm{CuH}-\mathrm{CLI}$

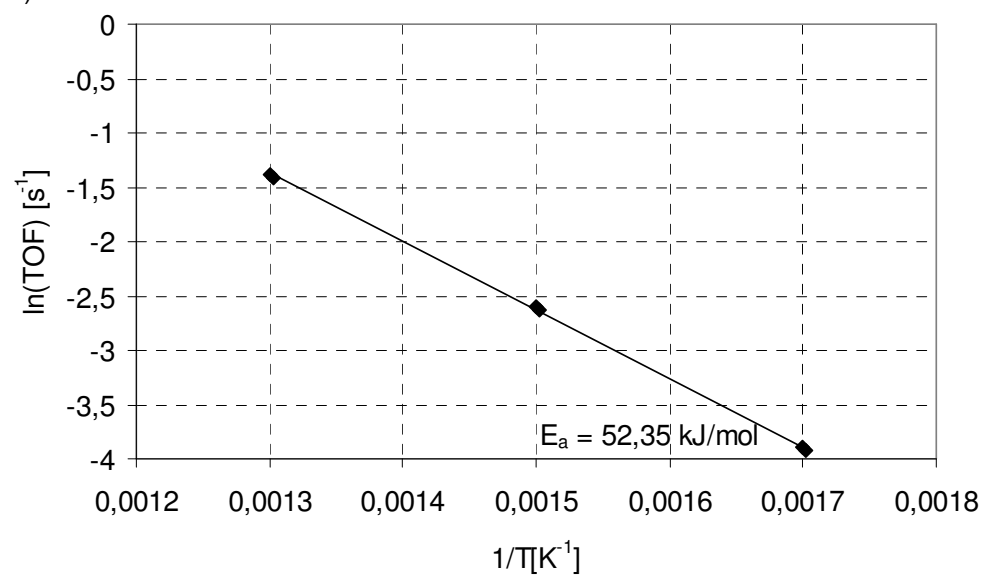

Fig. 8. Arrhenius plots of dependence of TOF the 1/T over $\mathrm{Cu}$ and Co-CLI catalysts.

Modify the zeolite the cation of metals in different degree, which permitted on examining from of ion modifying kind the dependence of activity of individual catalysts and degree of his exchange. The comparison of activity of individual contacts in aim of qualification their catalytic abilities permitted to establish among catalytic abilities mutual correlations and the parameters the physic-chemical of received catalysts the zeolite. The clinoptylolite the cobalt catalysts and copper they distinguish oneself both the content of metal, relation of metal to aluminum how and the size of proper surface of contact. Proprieties these confirm near comparison of activity of contacts. The maximum speed of reaction be shifted in direction of higher temperatures. Selectivity undergoes larger differentiation to nitrogen, the significant values of conversion were got already in $400^{\circ} \mathrm{C}$. 
c) $\mathrm{FeH}-\mathrm{CLI}$

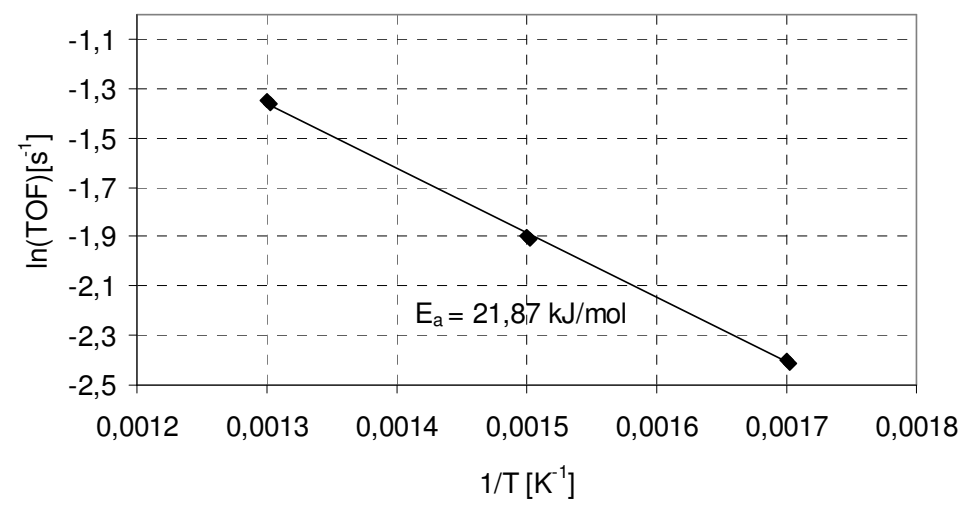

d) $\mathrm{MnH}-\mathrm{CLI}$

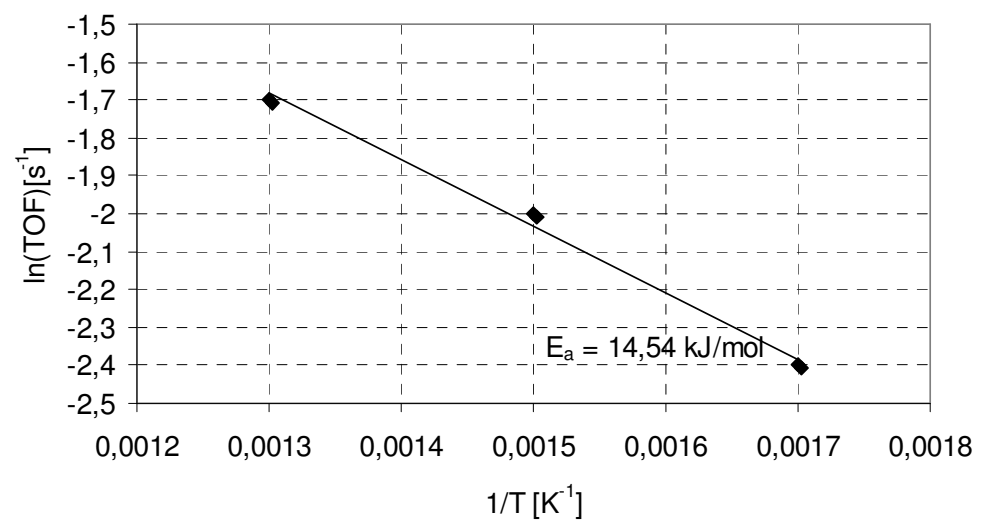

Fig. 9. Arrhenius plots of dependence of TOF he 1/T over Fe and Mn - CLI catalysts.

Tab. 2. Activation energies of used catalysts.

\begin{tabular}{|c|c|c|}
\hline Catalysts & $\mathrm{E}_{\mathrm{a}} \mathrm{kJ} / \mathrm{mol}$ & $\Delta \mathrm{E}_{\mathrm{a}}$ \\
\hline CuH-CLI & 52.35 & \pm 5.2 \\
\hline CoH-CLI & 67.10 & \pm 6.7 \\
\hline FeH-CLI & 21.81 & \pm 2.18 \\
\hline MnH-CLI & 14.54 & \pm 2.19 \\
\hline Ni-CLI & 12.46 & \pm 2.5 \\
\hline
\end{tabular}

Analyses of catalytic tests permit to affirm, that cobalt-copper form clinoptylolite reduces to nitrogen NO in enough wide range achieving conversion to nitrogen on level $78 \%$ in compartment of temperatures 450 - 
$500^{\circ} \mathrm{C}$ in presence of methane selectively. The methane for the two - component modified two kinds of ions catalyst was observed the strong effect the synergist in process of reduction the NO in comparison from including only one kind of cation catalysts simultaneously. Differences in activity of individual contacts result with their catalytic proprieties doubtless, though the degree of exchange of cation not without meaning stays in zeolite. The use of method of ion exchange permits to introduce in net the zeolite the different quantities of cation according from conditions the practical. The contacts the clinoptylolite the modified the ions $\mathrm{Co}$ - and the $\mathrm{Cu}$ - permit to get the considerable degree of conversion the NO but sale small the percentage of clean nitrogen, to the significant for process of reduction NO could stand the methane. It significant results were got was really in temperature $500^{\circ} \mathrm{C}$. In spite high thermal stability of structure and they can not be the good catalysts of process of reduction the significant activity in count on gram of catalyst.

Clinoptylolite with regard on one's low price, accessibility as well as propriety ionic renewable, molecular - sieve and catalytic good material can make up to removing from air different gas pollutions.

\section{REFERENCES}

[1] K. Piaskowski, A.M. Anielak, Zeolity naturalne i ich zastosowanie w oczyszczaniu wody oraz ścieków, Ekologia i Technika, 2, 31 (2000) (in Polish).

[2] G.I. Ciciszwili, T.G. Andronikaszwili, G.N. Kirow, L.D. Filizowa, Zeolity Naturalne. Wydawnictwo Naukowo-Techniczne, Warszawa (1990) (in Polish).

[3] R. Petrus, J. Warchoł, Chem. Ecol. Engn., 7, 327 (2000).

[4] J. Kaleta, D. Papciak, A. Puszkarkiewicz, Klinoptylolity i dolomity $w$ aspekcie przydatności, Gospodarka surowcami mineralnymi, 23, 3 (2007) (in Polish).

[5] Y. Traa, B. Burger, J. Weitcamp, Micropor. Macropor. Mater., 30, 3 (2000).

[6] P.A. Jacobs, Zeolite chemistry and catalysis, Amsterdam - Oxford - New York, Elsevier, (1991).

[7] M. Iwamoto, Studies in surface science and catalysis: Future opportunities in catalytic and separation technology, eds. M. Misono, Y. Morooka, S. Kimura, Elsevier, Amsterdam 121 (1990).

[8] R. Moreno-Tost, J. Santamaria-Gonzalez, E. Rodrigez-Castellon, A. Jimenez-Lopez, Appl. Catal., 50, 279 (2004).

[9] D. Kucky, A. Vondrova, J. Dedecek, J. Catal., 194, 318 (2000).

[10] O. Monticelli, R. Loendres, P.A. Jacobs, J.A. Martens, Appl. Catal. B: Environ., 21, 215 (1999).

[11] M. Ogura, S. Kage, T. Shimojo, J. Oba, M. Hayashi, M. Matsukata, J. Catal., 21, 75 (2002).

[12] L.B. Gutierrez, A.V. Boix, E.A. Lombardo, J.L. Fierrot, J. Catal., 199, 60 (2001).

[13] H. Chen, Q. Sun, B. Wen, Y. Yeom, E. Weitz, W. Sachtler, Catal. Today, 96, 1 (2004)

[14] J.N. Armor, Catal. Today, 26, 147 (1995).

[15] A. Kubacka, J. Janas, B. Sulikowski, Appl. Catal. B: Environ., 69, 43 (2006).

[16] I. Sobczak, M. Ziółek, Chem. Messages, 56, 177 (2002).

[17] J. Dedecek, O. Bortnovsky, A. Vondrowa, B. Wichterowa, J. Catal., 1, 60 (2001). 
[18] J. Barcicki, Basis of heterogeneous catalysis, Publishing house UMCS, Lublin, (1998).

[19] G.C. Bond, Catalysis would to metals, Academic Press London and New York (1962).

[20] G.C. Bond, Catal. Today, 49, 41 (1999).

[21] Z. Karpiński, R. Larsson, Stud. Surf. Sci. Catal., 79, 89(1993).

[22] J.N. Armor, Micropor. Mesopor. Mater., 22, 451 (1998).

\section{CURRICULUM VITAE}

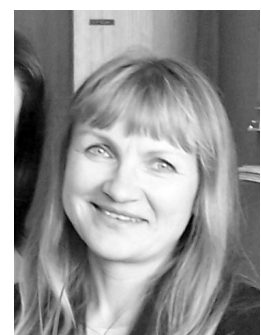

Wiesława Ćwikła-Bundyra. Born in Poland in 1966. Graduated from Maria Curie-Skłodowska in Lublin in 1989. Received her Ph.D. degree in 2003 in physical chemistry from the University of Maria Curie-Skłodowska in Lublin. Member of Polish Chemical Society and Polish Catalysis Club (since 1994). Her main field of interest is environmental catalysis. She published over 40 papers. 